\author{
MATEUSZ ŚWIETLICKI \\ Instytut Filologii Słowiańskiej \\ Uniwersytet Wrocławski
}

\title{
YOU ARE NOT A DOLL, NOT A COMMODITY! - CONTEMPORARY UKRAINIAN ADVICE LITERATURE FOR GIRLS
}

To say that advice literature plays a significant role in the process of forming individual and collective identity is to say nothing revolutionary. Such eminent scholars as Zygmunt Bauman, Judith Butler, Jean Baudrillard, Giorgio Agamben, Marcel Mauss, and Pierre Bourdieu all examined the significance of habits and social norms in their research on the concept of identity ${ }^{1}$. The importance of the changing nature of European habitus had already been discussed in 1939 by Norbert Elias in The History of Manners, the first part of his groundbreaking The Civilizing Process where he studies etiquette manuals and shows the multilayered nature of the concept of civilization ${ }^{2}$. In her thought-provoking book Refining Russia: Advice Literature, Polite Culture, and Gender from Catherine to Yeltsin Catriona Kelly challenges Elias and shows similarities and differences between the German and Russian processes of civilization. She discusses different types of advice literature and studies the complex relationship between Russian culture and the Western norms of conduct ${ }^{3}$. Unfortunately, a similar study devoted to Ukraine has not been published yet. In this article, I would like to discuss norms and behaviors present in contemporary Ukrainian advice literature for girls and show their role in the post-Soviet reemergence of patriarchal norms ${ }^{4}$. After familiarizing readers with sexual politics in the USSR and traditional gender roles in Ukraine, I will examine the history of advice literature for girls after

1 See Z. Bauman, Kultura i społeczeństwo. Preliminaria [Culture and Society, Preliminaries], Warszawa 1966; J. Butler, Gender Trouble: Feminism and the Subversion of Identity, New York 1999; J. Baudrillard, Simulacra and Simulation, trans. S. Glaser, Ann Arbor 1994; G. Agamben, The Use of Bodies, trans. A. Kotsko, Redwood City 2016; M. Mauss, Sociologie et Anthropologie, Paris 1968, pp. 364-386; P. Bourdieu, Distinction: A Social Critique of the Judgment of Taste, trans. R. Nice, Cambridge 1984.

${ }^{2}$ N. Elias, The Civilizing Process: Sociogenetic and Psychogenetic Investigations, trans. by E. Jephcott, Oxford 2000.

${ }^{3}$ C. Kelly, Refining Russia: Advice Literature, Polite Culture, and Gender from Catherine to Yeltsin, Oxford 2001.

${ }^{4}$ I will focus only on books originally written in Ukrainian. Some of the analyzed handbooks were also published in the Russian language. 
1989 and then focus on analyzing five representative books published in the last five years: A Real Lady. A Handbook for Girls (2012), A Book for Young Lady (2014), A 100\% Girl (2016), Encyclopedia for Girls (2016), and A Stylish Book for a Little Lady (2015).

\section{Soviet and post-Soviet norms}

In the Soviet Union literature emphasized the superiority of the East over the West. The state education system was an efficient tool for the creation of the new Soviet man: not only propaganda set books, but also a list of appropriate further reading were imposed on children $^{5}$. All of them, regardless of the origin of their parents, were supposed to live a similar and perfectly happy childhood. Understandably, a child reader was to be a universal and unisex figure whose reaction to the text could have easily been predicted. In Soviet Ukraine, literature proved to be an effective tool of not only ideological Sovietization but also linguistic Russification. Most children's books and magazines were published in the Russian language, and the few Ukrainian titles were usually less interesting for the young readers.

According to the family code introduced in 1918, Soviet men and women were equal. Women were integrated into the labor market and the new model of parenthood emerged. Mothers gained social and financial independence because of the state-owned nurseries and kindergartens; fathers' position of sole breadwinners was weakened ${ }^{6}$. Parenting began to be perceived as a task assigned to women with the help of the state and the role of the father in the upbringing of children was undermined. Thus, a new type of passive, Soviet fatherhood, appeared $^{7}$. The entire responsibility for the upbringing of children lay on working women. Despite the alleged equality in the public sphere, in the private sphere the state sought to restore women's traditional roles of wives and mothers. Consequently, women were responsible for the maintenance of the household, the upbringing of children, and paid work $^{8}$.

In the USSR division of literature for children according to gender was unaccepted since it was believed to be "bourgeois". Especially, since books for girls had been quite popular amongst the Eastern-European upper classes before $1917^{9}$. After 1991 gender differentiation became one of the most evident features of the post-Soviet sphere. This can be attributed to the popularization of traditional, pre-Soviet gender roles after the collapse of communism when "the critical response to the failure of the whole Soviet utopian project is reflected in a gender dynamic. In the arguments of post-Soviet and conservative state

${ }^{5}$ See C. Kelly, Refining Russia..., op.cit.

${ }^{6}$ И. Тартаковская, Гендерная соииология, Москва 2005, pp. 194-199.

7 Ж. Чернова, Модель советского отиовства: дискурсивные предписания, [in:] Российский гендерный порядок: соииологический поход: Коллективная монография, ред. Е. Здравомысловой, А. Темкиной, СПб 2007, pp. 138-168.

${ }^{8}$ S. Ashwin, Gender, state and society in Soviet and post-Soviet Russia, [in:] Gender, state and society in Soviet and post-Soviet Russia, ed. S. Ashwin, London 2000, pp. 1-29.

${ }^{9}$ L. Rudova, "Who's the fairest of them all?" Beauty and Femininity in Contemporary Russian Adolescent Girl Fiction, "The Russian Review" July 2014, 73, pp. 389-403. 
rebuilding, the essential falseness of the utopian project is proved by the fact that it attributed feminine features to men and masculine features to women, thus reversing the "natural" sex roles."10 During this "renaissance of patriarchy" (also known as "quiet" gender revolution) traditional, patriarchal gender patterns were to be restored.

After 1989 advice literature for children flourished and currently the Eastern-European book market is filled with handbooks for girls and boys of different ages. As noticed by Andrea Lanoux, a prominent feature of "Russian children's literature in the post-communist era has been the reassertion of gender difference in both the content of children's books (heroes, themes, and plots) and in their marketing strategies"11. This type of gender differentiation can also be found in Ukrainian bookstores. Handbooks for children are always released in two gender versions. Even though the covers are usually corresponding (the main difference is the color: blue for boys, pink for girls), their contents are often very different. Interestingly, there are no "how-to" books for both genders ${ }^{12}$.

Contemporary Ukrainian advice books are filled with patriarchal norms and ideas typical of consumerism, defined by Zygmunt Bauman as "type of social arrangement that results from recycling mundane, permanent and so to speak 'regime-neutral' human wants, desires, and longings into the principal propelling and operating force of society, a force that coordinates systemic reproduction, social integration, social stratification, and the formation of human individuals, as well as playing a major role in the processes of individual and group self-identification and in the selection and pursuit of individual life policies"13. Because of advice literature, girls learn to consume, which "means to invest in one's own social membership, which in a society of consumers translates as 'saleability': obtaining qualities for which there is already a market demand"14. As observed by Larissa Rudova, gendered literature "should therefore be considered not only within a literary sphere, as a product conceived with girls' interests and a middle-class system of values in mind, but also for its commercial content, as a literary commodity that symbolizes and sells a particular lifestyle and consumer products"15.

${ }^{10}$ I. Novikova, Soviet and Post-Soviet Masculinities: After Men's Wars in Women's Memories, in: Male Roles, Masculinities and Violence, ed. by I. Breines, R. Connell, I. Eide, 2000, p. 119.

11 A. Lanoux, Laundry, Potatoes, and the Everlasting Soul: Russian Advice Literature for Girls after Communism, "The Russian Review" July 2014, 73, p. 405.

12 Remarkably, in Poland there is only one similar encyclopedia for girls published in 2008 (A. Minkowski, Encyklopedia dla nastolatki, Wrocław 2008) and a few original and translated advice books about etiquette and puberty. (Such as Niezbędnik nastolatki. Wszystko co dziewczyny powinny wiedzieć, żeby być piękne, zdrowe i szczęśliwe, trans. by A.J. Mamińska, Poznań 2010; J. Krzyżanek, Dobre maniery Cecylki Knedelek, czyli o tym, że wypada wiedzieć, że wypada, Kielce 2015.) Moreover, some of them are for boys and girls with no gender differentiation (Such as G. Herbst, Dobre maniery czyli savoir vivre dla dzieci i nie tylko, Kraków 2014; M. Przewoźniak, J. Jabłczyńska, Niezbędnik dobrych manier dla nastolatków, Poznań 2015) - something unprecedented in Ukraine or Russia.

13 Z. Bauman, Consuming life, Cambridge 2007, p. 28 (emphasis in original).

14 Ibidem, p. 56.

${ }^{15}$ L. Rudova, “Who's the fairest of them all?”, op. cit., p. 389. 


\section{Advice literature for girls}

Even though Encyclopedia for Girls, one of the first and most popular examples of post-Soviet advice literature was published in 1989 in $\mathrm{Kyiv}^{16}$, handbooks for girls written in Ukrainian became popular later than their Russian equivalents. Russian advice literature from this period echoes the socio-political transition after the collapse of the Soviet Union, "when Western cultural imports were entering Russia at lightning speed but had not yet transformed Soviet-era notions of social relations, cultural canons, or gendered norms of behavior" ${ }^{17}$. Russian handbooks of the 1990s consisted of a selection of different and intersecting subjects, such as housework; pastime activities; culture and moral education; etiquette; health; hygiene and sexuality; beauty tips; fashion; as well as personality (frequently presented in the form of character tests or horoscopes $)^{18}$. In the early 2000 s, Ukrainian advice literature flourished, more than 10 original pieces of advice literature titled Encyclopedia for Girls were published between 2000 and 2006 ${ }^{19}$. Most of them were not particularly original and recalled the Russian books from the early 1990s, especially the one published by Iakovenkos' in 1989.

In 2006 Kraina Mriy, one of Ukraine's biggest publishers specializing in children's literature, released A Little Lady. A Handbook for the 21 $1^{\text {st }}$ Century Girl which became the most popular Ukrainian handbook for pre-teens and teens after 1989. Written by Tetyana Shcherbachenko (now known as Tania Stus) ${ }^{20}$ it became a bestseller, selling more than 30,000 copies - a remarkable achievement in Ukraine ${ }^{21}$. Shcherbachenko tried to challenge the previous stereotypical books by dividing the world of a typical girl into three platforms: the inner world, the surrounding world (fashion, style), and the parallel world, focusing on a balanced relationship between the "body and soul".

With a lot of text and no colorful illustrations, by 2011 A Little Lady seemed dated. Kraina Mriy decided to release its new, modernized edition, but due to some artistic differences, Shcherbachenko declined to update $\mathrm{it}^{22}$. Nevertheless, in 2012 A Real Lady. A Handbook for Girls was published without her permission ${ }^{23}$. It is a similar book but this time

16 Г.П. Яковенко, Н.Г. Яковенко, Эничиклопедия для девочек. Любому возрасту полезна, Киев 1993.

17 A. Lanoux, Laundry, Potatoes, and the Everlasting Soul, op. cit.

18 Ibidem.

19 See Н.М. Волчек, Енцииклопедія для дівчат, Київ 2001, 2004, 2005; I. Гончаренко, Енциклопедія для юних ледi, Харків 2002; Ю. Полякова, Сучасна енциклопедія для дівчаток, Донецьк 2003; А. Снєгірьова, Енциклопедія для дівчат: Перше кохання, Київ 2003; М.О. Хаткіна, Улюблена енциклопедія для дівчаток, Донецьк 2004; О.Я. Кривич, Енциклопедія для дівчаток, Харків 2006; М.О. Хаткіна, Чудова енциклопедія для сучасних дівчаток: 1000 відповідей на непрості запитання, Донецьк 2006; Є.Т. Братчина, Усе для дівчаток: Дитяча енииклопедія, Харків 2006; Г.Д. Швець, Енииклопедія домашніх справ для дівчаток, Київ 2007; Translations from English also became very popular see: A. Найк, Енциклопедія для дівчаток. Перше побачення. Погляд у майбутнє, Харків 2002; А. Найк, Енциклопедія для дівчаток: дівочі турботи. Виховання самоповаги, Харків 2003.

20 Т. Щербаченко, Панночка. Книга дівчинки XXI століття, Київ 2006.

21 Т. Щербаченко, Панночка виросла. А видавціi, http://bukvoid.com.ua/column/2012/12/19/145857.html (01.02.2017).

22 Ibidem.

23 Справжня панянка. Порадник для дівчат, Київ 2014. 
there is less text and a lot of colorful illustrations. The cover is pink and, according to the publisher, it is a sequel to A Little Lady (which was written for 7-14 year-olds). While Sherbachenko did discuss issues such as fashion and cooking, A Real Lady appears to promote a much more stereotypical model of femininity. This time girls do not learn about the relationship between the "body and soul" - it is all about their "saleability". Written by various authors and illustrated by Olga Voronkova, A Real Lady consists of 312 pages filled with information necessary for a young lady. The first chapter discusses styles and clothing suitable for one's body type (still, only four are introduced - pear, hourglass, inverted triangle, straight) and ends with a quiz titled "Are you stylish?" (6 pages). The next ones are also devoted to various issues concerning beauty and looks, including DIY jewelry (15 pages); hygiene - with tips on menstruation, as well as choosing the right toothpaste and soap (11 pages); make-up (10 pages); hairstyles (5 pages); finding the right perfume (5 pages). The discourse changes noticeably in the seventh chapter where housekeeping is discussed. Girls learn about things such as vacuuming, ironing, removing common clothing stains, cleaning windows, floors, and carpets (23 pages) Next the authors discuss health and "feminine" sports which can help girls keep in shape, such as aerobics, jogging, and cycling ( 9 pages). One of the longest chapters (20 pages) discusses throwing parties, including tips on costumes, homemade snacks, and games - it also ends with a quiz, this time called "Are you a good friend?". The next part is a continuation of the previous chapter on sports - here girls discover rollerblading and ice-skating - free time activities suitable for a girl (8 pages). The second longest part of the book is called "A great cook" and consists of 46 pages filled with recipes that every Ukrainian girl should know (including some difficult ones for cakes, desserts, fish, and meat). The last chapter, consisting of 119 pages, is the longest one. Remarkably, it is devoted to discovering one's personality through different types of horoscopes, a dream-book, and a long list of names with their meanings attached. Interestingly, here we do not find any information on relationships, sex, job opportunities, or etiquette. The authors teach girls that their duties consist of looking pretty, taking care of the household, and cooking. In their free time, they can read horoscopes, put on make-up, throw parties, or go rollerblading.

By 2011 Kraina Mriy had competition. Encouraged by the success of A Little Lady, the publishing house Shkola released their own handbook for little ladies titled A $100 \%$ Girl (edited and illustrated by Evhenia Zhytnyk) ${ }^{24}$. The second, extended edition appeared in 2016. According to the publisher, it is a handbook for pre-teens. Even though it seems similar to A Real Lady, it represents a new - less Soviet and more Western - model of advice literature. Zhytnyk introduces new topics and pays little attention to housekeeping and cooking. The first chapter deals with such diverse issues as acne, body hair, growing breasts, menstruation, and first appointment with the gynecologist, well-balanced diet, anorexia, bulimia, and sport (40 pages). The second one discusses beauty secrets, style, and clothes (20 pages). The following chapters are devoted to free time activities (such as dancing, reading, computers, outdoor activities, traveling - 32 pages); friendships and relationships with parents (including fragments about divorce and adoption - 26 pages); relationships with boys (the author highlights natural differences between men and women, there are fragments called "how not to lose him," how to use "body language," and "what

${ }^{24}$ Є. Житни, Дівчинка на 100\%, Харків 2016. 
type of girls boys like"). Unlike in A Real Lady, here girls learn about kissing, sex (the author says that if a girl does not want to do it, she should say no: "Don't be stupid! Use your brains" [142]), birth control, HIV/AIDS, STDs, teenage pregnancy (including its dangers), and abortion (20 pages). Even though sex is openly discussed, just like in other Eastern-European handbooks there is no mention of non-heteronormative sexualities. In the following chapter the author studies holidays and celebrations (20 pages); good manners (how to be a real lady - an issue absent from A Real Lady - 18 pages); housework and cooking (focusing on taking care of one's own room - 27 pages); pets (11 pages); emotions, personality, mood changes (34 pages); hazards such as narcotics, cigarettes, alcohol, pornography, children pornography ("You are not a doll, not a commodity!" she says), and once again the dangers of sex, HIV and STDs (34 pages). The last chapter discusses horoscopes and beliefs (31 pages). A 100\% Girl promotes less stereotypical behaviors and models of femininity; the author introduces problematic issues absent from the previously discussed books. Still, the book highlights the "natural" differences between men and women, popularizing the idea that women should aspire to marriage and that some professions are only for men, while others only for women.

In 2016 a new book titled Encyclopedia for Girls was released. According to the publishing house Gloria, it is supposed to be a "faithful friend" to all teenage girls who want to learn about being a loyal mate, daughter, and student; discover secrets of beauty and style; and finally, become a charming, successful, and appealing young lady ${ }^{25}$. Albeit it shares the name with the encyclopedias from the early $00 \mathrm{~s}$, it is similar to other contemporary handbooks. Authors or editors of the volume are unknown. Despite its name, Encyclopedia for Girls is a relatively short book (128 pages) consisting of nine chapters of similar length. Unlike the previously discussed books, this one may be seen as more appealing as it includes photographs. While the anonymous authors focus on looks, beauty, cooking, and domestic chores, Encyclopedia for Girls includes some useful information on relations with parents, classmates and teachers, good manners, first aid and security at home and school, free time activities, and puberty. Two chapters are especially challenging. In "Real friends" readers learns about cliques and friendships with boys. Girls are taught that sometimes boys bully girls because they like them. In response girls should ignore boys and change their own attitude - only then a real friendship is possible. "You're all grown up!" discusses horoscopes, differences between love and infatuation (including a list of 'things a boy who really likes you say' and 'things a boy who wants to take advantage of you say'); sex (described as something dangerous, there is a very brief mention of AIDS referred to as 'the plague', and a short sentence about contraception); and pregnancy. According to the authors, motherhood equals womanhood and pregnancy at the age of 13-19 is extremely dangerous. On the one hand, abortion can lead to infertility and serious health problems. On the other hand, giving birth at a young age makes it impossible for a girl to go to college or university and find a good job because she becomes alienated and bullied (121). Even though Encyclopedia for Girls contains some useful information, it reinforces male domination and gender stereotypes (including the "natural" differences between boys and girls), as well as stigmatizes sex, abortion, and teenage pregnancy.

\footnotetext{
25 Енцииклопедія для дівчаток, Київ 2016.
} 
Oksana Karavanska, author of the last book I want to analyze, is one of the most popular fashion designers in Ukraine ${ }^{26}$. In 2015 Vydavnytstvo Staroho Leva, one of the leading Ukrainian publishers specializing in high-quality children's literature, published her debut book A Stylish Book for a Little Lady with illustrations by Anastasia Stefurak ${ }^{27}$. Stefurak's beautiful illustrations not only complete the text but also give it additional meaning ${ }^{28}$. It is not a typical handbook; one may treat it as a hybrid of an autobiographical picture book and a handbook. According to the publisher, it is an educational picture book for 8-12 year-old girls.

Topics discussed here include clothes, accessories, make-up, hairstyles, but also the history of fashion and trends. As Karavanska said in an interview promoting the book: "[Ukrainian] children don't have a handbook that would show them how important fashion is [...] You don't have to wear expensive clothes - you have to be stylish [...] we may like it or not, but people are always judged by their fashion choices" ${ }^{29}$. After reading Stylish Book... one may assume that Karavanska simply wants to promote her brand and find new, younger customers. Her book is filled with ideas typical of consumerism. The shiny, pink cover is supposed to look like a glossy fashion magazine. It consists of sixteen chapters, including an introduction where Karavanska presents herself to the readers. Most chapters are overlapped by autobiographical childhood stories connected to fashion and style, accompanied by collages of Stefurak's pictures and Karavanska's old photographs. Remarkably, her childhood self is the only child in the book with a human-like face, others resemble emotionless mannequins.

Even though Karavanska states that fashion should not become the center of girls' lives, she teaches them that clothes and dress codes are exceptionally important. "Don't forget that even when you don't want to be seen, someone important can notice you" ${ }^{30}$, she says. After introducing four types of clothing - classic, casual, unisex "this one is the least sexy" ${ }^{\prime 1}$, and street fashion - she focuses on the importance of individuality. Just like other similar books, this one reinforces gender stereotypes, especially in fragments such as: "When you want to go out dancing, of course, you don't want to just dance, but [you want to] make boys like you. Your mom may not like me for saying this, but you can't be modest [...] You should be noticeable"32; or "Are you going on a date? [...] Spend as much time in front of the mirror as is required to make you look great. If you don't like the way you look, you will be nervous and your boyfriend will notice it!" 33 . Nevertheless, she introduces issues absent from the previously discussed handbooks. A long part of the book is devoted to the presentation of subcultures and things stereotypically connected with

${ }^{26}$ She designs clothes for women, men, children, and has her own line of accessories: OK' by oksanakaravanska, OKIDS' by oksanakaravanska, OK' by oksanakaravanska for men, Oksana Karavanska Accessories.

27 О. Караванська, Стильна книжка для панянки, Львів 2014.

${ }^{28}$ See W.J.T. Mitchell, Iconology: Image, Text, Ideology, Chicago 1986, p. 89.

${ }^{29}$ Оксана Караванська про моду та не галицький Львів, http://starylev.com.ua/news/oksana-karavanska-pro-modu-ta-ne-galyckyy-lviv (01.02.2017).

${ }^{30}$ О. Караванська, Стильна книжка..., ор.cit., p. 98.

31 Ibidem, p. 19.

32 Ibidem, p. 100.

33 Ibidem, p. 26. 
them. She discusses emos, goths, hipsters, and freaks then criticizes and dismisses the first three subcultures because when a girl joins a subculture, she loses her originality. Karavanska is less skeptical of the last one: "even though the society treats freaks as curiosities, they are often talented and creative individuals", she says ${ }^{34}$. One can only assume she identifies as a freak. Karavanska also promotes vyshyvanky (traditional embroidered shirts), saying that a real Ukrainian girl should have at least a few. She recommends buying hand -made designer ones (Karavanska is known for popularizing them in the West). While this chapter contains some educational values, as she introduces different types of regional embroidered shirts with all of their characteristic features, it may also be seen as an indirect advertisement of her own brand.

One of the most challenging parts of the book talks about body types. "There are no ugly girls - there are only some lazy ones!" ${ }^{35}$, she says. In the fourth chapter Karavanska compares two body types - skinny and fat - and recommends best clothing for both, focusing on the fact that "At the age of 8-12 girls gain weight and the so-called pre-teen belly appears $[\ldots]$ that's why you shouldn't wear tight clothes [...] tight clothes make a girl look sexy"36. Here the relationship between the image and the text is crucial, as both girls drawn by Stefurak look the same. There is no difference between fat and skinny. One may only argue that this can lead to a distorted perception of a girl's body type.

As previously mentioned, A Stylish Book for a Little Lady is supposed to be an educational book. With no doubt, it teaches girls to be good consumers, as it is filled with direct and indirect product placement. We can find numerous products and logos, such as YSL, Chanel, Ralph Laurent, Guerlain, and Marc Jacobs. Some appear between the lines, other in the pictures. Karavanska provides young readers with a must-have list of a real young lady, including expensive designer perfumes. Girls learn that it is not right to buy fakes and that when their mothers buy them things on sale it does not mean they want to save money on them. Because of sales and bargains, they can get more for less - that is why girls should always encourage their moms to go shopping during the sales season.

The most attention-grabbing parts of the book are short chapters called "What is fashion?" (8 pages) and "How not to become a fashion victim" (7 pages) where Karavanska discusses the history of fashion, as well as the constantly changing trends. On the last page, she states: "nowadays it is not worth it to be like somebody else. Don't try to be like actresses, singers, or models [...] It's all business: they just want to make money $[\ldots]$ then you become a fashion victim [...] I don't think you wanted it when you became obsessed with [...] P!nk or Katy Perry." ${ }^{37}$ Even though her statement seems reasonable since girls should try to "be themselves", Karavanska's vision of "oneself" is quite narrow. If you do not fit into it, you cannot be a stylish little lady.

Karavanska claims that there have been no similar books to A Stylish Book for a Little Lady in Ukraine. Still, when we compare it with A Real Lady. A Handbook for Girls, A Book for Young Lady, or A $100 \%$ Girl the most noticeable difference is the much better illustrations. Noticeably Karavanska focuses on fashion and looks, in her book there is no

\footnotetext{
34 Ibidem, p. 118.

35 Ibidem, p. 34.

36 Ibidem.

37 Ibidem, p. 139.
} 
mention of issues such as sex and horoscopes, but apart from the fragments on the history of fashion, most of the things had already been discussed in Ukrainian handbooks for little ladies.

\section{Conclusions}

Not being skeptical about Ukrainian advice literature is challenging. Filled with patriarchal ideas, most of the "how-to" books teach girls to commodify themselves. Moreover, by promoting a single version of femininity they show girls what is, and what is not, achievable for a girl. The "girls' world" which emerges from Ukrainian advice literature is one of the very limited perspectives; girls learn how to sell themselves and consequently become slaves to gender norms and physical appearance. Still, it is possible to look at advice literature from a more positive perspective. It not only promotes certain patterns of behavior but also teaches girls social skills and helps them deal with difficult topics, especially those that are still being treated as taboos by many parents. Unfortunately, similarly to their Russian equivalents, Ukrainian handbooks, products of the "renaissance of patriarchy", promote patriarchal values and discuss gender roles in a very stereotypical way.

\section{Bibliography}

Agamben G., The Use of Bodies, trans. A. Kotsko, Redwood City 2016.

Ashwin S., Gender, state and society in Soviet and post-Soviet Russia, [in:] Gender, state and society in Soviet and post-Soviet Russia, ed. S. Ashwin, London 2000, pp. 1-29.

Baudrillard J., Simulacra and Simulation, trans. S. Glaser, Ann Arbor 1994.

Bauman Z., Consuming life, Cambridge 2007.

Bauman Z., Kultura i społeczeństwo. Preliminaria [Culture and Society, Preliminaries], Warszawa 1966.

Bourdieu P., Distinction: A Social Critique of the Judgment of Taste, trans. R. Nice, Cambridge 1984.

Butler J., Gender Trouble: Feminism and the Subversion of Identity, New York 1999.

Elias N., The Civilizing Process: Sociogenetic and Psychogenetic Investigations, trans. by E. Jephcott, Oxford 2000.

Herbst G., Dobre maniery czyli savoir vivre dla dzieci i nie tylko, Kraków 2014.

Kelly C., Refining Russia: Advice Literature, Polite Culture, and Gender from Catherine to Yeltsin, Oxford 2001.

Krzyżanek J., Dobre maniery Cecylki Knedelek, czyli o tym, że wypada wiedzieć, że wypada, Kielce 2015.

Lanoux A., Laundry, Potatoes, and the Everlasting Soul: Russian Advice Literature for Girls after Communism, "The Russian Review" July 2014, 73, pp. 404-426.

Mauss M., Sociologie et Anthropologie, Paris 1968, pp. 364-386.

Minkowski A., Encyklopedia dla nastolatki, Wrocław 2008.

Mitchell W.J.T., Iconology: Image, Text, Ideology, Chicago, 1986.

Niezbędnik nastolatki. Wszystko co dziewczyny powinny wiedzieć, żeby być piękne, zdrowe i szczęśliwe, trans. by A.J. Mamińska, Poznań 2010. 
Novikova I., Soviet and Post-Soviet Masculinities: After Men's Wars in Women's Memories, [in:] Male Roles, Masculinities and Violence, ed. by I Breines, R. Connell, I. Eide, 2000, p. 119.

Przewoźniak M., Jabłczyńska J., Niezbędnik dobrych manier dla nastolatków, Poznań 2015.

Rudova L., "Who's the fairest of them all?" Beauty and Femininity in Contemporary Russian Adolescent Girl Fiction, "The Russian Review" July 2014, 73, pp. 389-403.

Świetlicki M., Kiedy chłopcy zostaja mężczyznami? Męskość jako projekt w prozie Serhija Żadana, Wrocław 2016.

Найк А., Енциклопедія для дівчаток: дівочі турботи. Виховання самоповаги, Харків 2003.

Братчина Є.Т., Усе для дівчаток: Дитяча енщиклопедія, Харків 2006.

Волчек Н.М., Енциклопедія для дівчат, Київ 2001, 2004, 2005.

Енииклопедія для дівчаток, Київ 2016.

Житни Є., Дівчинка на 100\%, Харків 2016.

Караванська О., Стильна книжка для панянки, Львів 2014.

Кривич О.Я., Енцикллопедія для дівчаток, Харків 2006.

Найк А., Енщиклопедія для дівчаток. Перше побачення. Погляд у майбутнє, Харків 2002.

Оксана Караванська про моду та не галицький Львів, http://starylev.com.ua/news/oksana-karavanska-pro-modu-ta-ne-galyckyy-lviv (01.02.2017)

Полякова Ю., Сучасна енциклопедія для дівчаток, Донецьк 2003.

Снєгірьова А., Енциклопедія для дівчат: Перше кохання, Київ 2003.

Справжня панянка. Порадник для дівчат, Київ 2014.

Тартаковская И., Гендерная социология, Москва 2005, pp. 194-199.

Хаткіна М.О., Улюблена енциклопедія для дівчаток, Донецьк 2004.

Хаткіна М.О., Чудова енщиклопедія для сучасних дівчаток: 1000 відповідей на непрості запитання, Донецьк 2006.

Чернова Ж., Модель советского отиовства: дискурсивные предписания, [in:] Российский гендерный порядок: сочиологический поход: Коллективная монография, ред. Е. Здравомысловой, А. Темкиной, СПб 2007, pp. 138-168.

Швець Г.Д., Енциклопедія домашніх справ для дівчаток, Київ 2007.

Щербаченко Т., Панночка виросла. А видавціi?, http://bukvoid.com.ua/column/2012/12/19/145857. html (01.02.2017)

Щербаченко Т., Панночка. Книга дівчинки ХХІ століття, Київ 2006.

Яковенко Г.П., Яковенко Н.Г., Энщиклопедия для девочек. Любому возрасту полезна, Киев 1993.

\section{MATEUSZ ŚWIETLICKI}

\section{You are not a doll, not a commodity! - Contemporary ukrainian advice literature for girls}

\section{Summary}

The author of the article focuses on the stereotypical depiction of femininity in contemporary Ukrainian advice literature. By discussing norms and patterns of behavior present in Ukrainian advice literature for girls, he shows their role in the post-Soviet reemergence of patriarchal norms. The article focuses on five books published in the last five years: A Real Lady. A Handbook for Girls (2012), A Book for a Young Lady (2014), A 100\% Girl (2016), Encyclopedia for Girls (2016), and A Stylish Book for a Little Lady (2015).

Keywords: advice literature, girlhood, Ukraine, children's literature 